\title{
Histone H4 Gene
}

National Cancer Institute

\section{Source}

National Cancer Institute. Histone H4 Gene. NCI Thesaurus. Code C154303.

A gene encoding the core histone protein histone $\mathrm{H} 4$. 